\title{
Comparison of biological effect of the two different enterotoxin complexes isolated from three different strains of Bacillus cereus
}

\author{
Terje Lund and Per Einar Granum
}

Department of

Pharmacology,

Microbiology and Food

Hygiene, Norwegian

College of Veterinary

Medicine, PO Box 8146

Dep., N-0033 Oslo, Norway
Author for correspondence: Per Einar Granum. Tel: +47229648 45. Fax: +4722964850. e-mail: Per.E.Granum@veths.no

\begin{abstract}
The cytotoxicity of the two different enterotoxin complexes of Bacillus cereus was compared after isolation from three different strains. Protein components of non-haemolytic enterotoxin (NHE) of $39 \mathrm{kDa}, 45 \mathrm{kDa}$ and $105 \mathrm{kDa}$ were isolated from all of the three strains, whilst proteins $B, L_{1}$ and $L_{2}$ of haemolysin BL (HBL) were isolated from supernatants of two strains (F837-76 and 1230-88). These proteins were not detected in strain 0075-95. Inhibition of protein synthesis in Vero cells was used as a measure of cytotoxicity. The HBL complex from strain F837-76 was highly toxic. This strain also produced the NHE complex. However, when purified, at least two of the components of NHE had to be present in higher amounts than those of the components of HBL to cause the same degree of toxicity. Both complexes purified from strain 1230-88 were cytotoxic. The amount required to cause the same degree of cytotoxicity was approximately equal for the components of the two complexes, except that higher amounts of the $105 \mathrm{kDa}$ protein of NHE had to be present than for the other components. None of the purified complexes from strain 1230-88 was toxic in amounts comparable to those of the HBL complex of strain F837-76 and NHE of strain 0075-95. These results indicate that when measuring cytotoxic enterotoxins from B. cereus at least two different complexes and six different proteins have to be taken into consideration.
\end{abstract}

Keywords: Bacillus cereus, enterotoxin, haemolysin

\section{INTRODUCTION}

Bacillus cereus is responsible for diarrhoeal and emetic types of food poisoning, which are caused by different toxins (for reviews see Granum, 1997; Kramer \& Gilbert, 1989). The diarrhoeal type of food poisoning is caused by enterotoxin(s) produced during vegetative growth of the bacteria in the small intestine (Granum, 1994).

Different enterotoxin complexes of $B$. cereus have been described. Haemolysin BL (HBL), containing the protein components $B, L_{1}$ and $L_{2}$, has been well characterized. The $\mathrm{B}$ component was cloned and sequenced by Heinrichs et al. (1993) and the entire HBL operon characterized recently by Ryan et al. (1997). This complex has haemolytic, dermonecrotic and vascular permeability

Abbreviations: HA, hydroxylapatite; HBL, haemolysin BL (haemolytic enterotoxin); $B$, binding protein of $H B L_{;} L_{1}$ and $L_{2}$, lytic proteins of HBL; NHE, non-haemolytic enterotoxin; ReQ, Resource Q. activities, and causes fluid accumulation in ligated rabbit ileal loops (Beecher \& Wong, 1994a, 1997; Beecher et al., 1995). HBL has therefore been suggested to be a primary virulence factor in $B$. cereus diarrhoea (Beecher et al., 1995). The components of HBL have been isolated only from strain F837-76, although multicomponent enterotoxins from other strains of $B$. cereus, containing similar proteins, have been reported by others (Thompson et al., 1984; Bitsaev \& Ezepchuk, 1987). In HBL and the related complexes all three components were required for maximal activity. Another, non-haemolytic enterotoxin (NHE) complex, consisting of proteins of molecular mass 39,45 and $105 \mathrm{kDa}$, which together are cytotoxic in low amounts, has been isolated from a strain which caused a large food poisoning outbreak (Lund \& Granum, 1996). Some similarities between $\mathrm{L}_{1}$ and the $39 \mathrm{kDa}$ protein in size and amino acid sequence at the $\mathrm{N}$-terminus have been shown, and it has been suggested that they might be homologous proteins in the two different strains (Lund \& Granum, 1996). Although some components of possible enterotoxin complexes are 
known, the understanding of the molecular nature of $B$. cereus virulence is limited.

Two commercial immunoassays for identifying enterotoxic strains of $B$. cereus are currently available. One of the assays detects the $\mathrm{L}_{2}$ component of $\mathrm{HBL}$, whilst the other detects the $45 \mathrm{kDa}$ protein of the NHE complex (Beecher \& Wong, 1994b; Lund \& Granum, 1996).

HBL and NHE have each been isolated from only one strain of B. cereus (F837-76 and 0075-95, respectively) and in different laboratories. The activity of the two complexes has never been compared with respect to toxicity. We have therefore isolated and compared the cytotoxicity of the two enterotoxin complexes from three different $B$. cereus strains.

\section{METHODS}

Strains, culture medium and culture conditions. Strains F83776 (Turnbull et al., 1979), 1230-88 (Granum et al., 1993) and 0075-95 (Lund \& Granum, 1996) were used for enterotoxin production. Strain F837-76, an isolate from a surgical wound infection, was obtained from J. M. Kramer, Public Health Laboratory Services, London. The other strains were responsible for outbreaks of diarrhoeal syndrome food poisoning in Norway in 1988 and 1995, respectively. The culture medium used for production of enterotoxins was a modification of the CGY medium (Beecher \& Wong, 1994a), consisting of $2 \%$ casein hydrolysate (Merck), $0.4 \%$ glucose, $0.6 \%$ yeast extract, $0.2 \%\left(\mathrm{NH}_{4}\right)_{2} \mathrm{SO}_{4}, 1.8 \% \mathrm{~K}_{2} \mathrm{HPO}_{4}, 0.2 \%$ $\mathrm{KH}_{2} \mathrm{PO}_{4}, 0 \cdot 1 \%$ sodium citrate and $0 \cdot 2 \% \mathrm{MgSO}_{4}$. The cells were grown at $32{ }^{\circ} \mathrm{C}$ for $5 \mathrm{~h}$ and EDTA $(1 \mathrm{mM})$ was added at the time of harvesting. Extracellular proteins were separated from the cells by centrifugation $\left(10000 \mathrm{~g}\right.$ at $4{ }^{\circ} \mathrm{C}$ for $\left.20 \mathrm{~min}\right)$.

Purification of proteins. The purification schemes were similar to those previously described in detail for purification of $\mathrm{HBL}$ (Beecher \& Wong, 1994a) and NHE (Lund \& Granum, 1996). DEAE-Sephacel (Pharmacia) was, however, used instead of Whatman DE-52. Proteins from 3 litres culture supernatant were precipitated with $70 \%$ saturated $\left(\mathrm{NH}_{4}\right)_{2} \mathrm{SO}_{4}$, resuspended in $40 \mathrm{ml}$ water and dialysed overnight at $4{ }^{\circ} \mathrm{C}$ against 1 litre $25 \mathrm{mM}$ Bistris/ $\mathrm{HCl}$, containing $1 \mathrm{mM}$ EDTA (pH 6.0), with two buffer changes. DEAE-Sephacel (Pharmacia) was packed into a column (diameter $1.6 \mathrm{~cm}$, height $10 \mathrm{~cm}$ ) and equilibrated with $25 \mathrm{mM}$ Bistris $/ \mathrm{HCl}(\mathrm{pH} \mathrm{6.0)}$. Proteins were eluted with a linear gradient of $\mathrm{NaCl}$ from 0 to $0.5 \mathrm{M}$ over $200 \mathrm{ml}$. Chromatography was carried out as described by Lund \& Granum (1996) and selected fractions from chromatography were pooled and applied directly to a column of BioGel HT hydroxylapatite (HA) (Bio-Rad). Selected fractions from $\mathrm{HA}$ were dialysed overnight at $4{ }^{\circ} \mathrm{C}$ against $20 \mathrm{mM}$ triethanolamine (Sigma) containing $1 \mathrm{mM}$ EDTA, with two buffer changes. The $\mathrm{pH}$ of the buffer was $7 \cdot 5$ for fractions containing the $105 \mathrm{kDa}$ protein, $8 \cdot 1$ for fractions containing the $39 \mathrm{kDa}$ protein and 7.8 for fractions containing the other proteins. Dialysed fractions were finally applied to a Resource $\mathrm{Q}(\mathrm{ReQ})$ column (1 ml) (Pharmacia), equilibrated with $20 \mathrm{mM}$ triethanolamine at the same $\mathrm{pH}$ as the dialysis buffer. Proteins were eluted in $20 \mathrm{mM}$ triethanolamine with a linear gradient of $\mathrm{NaCl}$ from 0 to $0.5 \mathrm{M}$ over $40 \mathrm{ml}$. Protein concentrations were estimated by measuring absorbance at $260 \mathrm{~nm}, 280 \mathrm{~nm}$ and $320 \mathrm{~nm}$.

Enzymic cleavage. The $105 \mathrm{kDa}$ proteins of the three strains $\left(0 \cdot 2-0.3 \mathrm{mg} \mathrm{ml}^{-1}\right)$ were treated with trypsin (Sigma) $(50: 1$, $\mathrm{w} / \mathrm{w})$ for $1 \mathrm{~h}$ at $37^{\circ} \mathrm{C}$ at $\mathrm{pH} \mathrm{7 \cdot 8.} \mathrm{The} 45 \mathrm{kDa}$ protein of strain 0075-95 (38 $\left.\mathrm{g} \mathrm{m} \mathrm{ml}^{-1}\right)$ was treated with the same enzyme $(50: 1$, $\mathrm{w} / \mathrm{w})$ for $30 \mathrm{~min}$ at $37^{\circ} \mathrm{C}$ at $\mathrm{pH} 7 \cdot 8$.

Protein sequencing. Purified proteins were sequenced from the $\mathrm{N}$-terminus by Edman degradation using an Applied Biosystems 477A automatic sequence analyser with an on-line $120 \mathrm{~A}$ phenylthiohydantoin amino acid analyser.

Electrophoresis. SDS-PAGE was carried out using a Bio-Rad Mini-Protean II Dual Slab Cell. The gels ( $10 \%$ acrylamide) were stained using the Bio-Rad Silver Stain Plus kit, and the molecular mass of the proteins were estimated using Bio-Rad SDS-PAGE low-molecular-mass standards.

Vero cell assay. Toxicity was determined using the inhibition of protein synthesis in Vero cells as an assay, according to Sandvig \& Olsnes (1982). The toxin concentrations were chosen in ranges which allowed an estimate of the concentrations giving $50 \%$ inhibition. The experiments were repeated twice and mean values are given. In some experiments the Vero cells were incubated with one of the toxin components for $15 \mathrm{~min}$. The cells were then washed in the growth medium and new medium containing the two other components was added. The subsequent procedure was identical to the procedure when all three components were added at the same time.

Kit for detection of enterotoxin. The Bacillus Diarrhoea Enterotoxin (BDE) Visual Immunoassay kit from Tecra was used according to the instruction manual.

\section{RESULTS}

Proteins from supernatants from strains F837-76, 1230 88 and $0075-95$ of $B$. cereus were precipitated with ammonium sulphate. SDS-PAGE with silver staining of the precipitates revealed at least 20 extracellular protein bands from each strain, but each strain showed a different pattern (Fig. 1). Chromatography on DEAESephacel at $\mathrm{pH} 6.0$ was used as the first step to purify the

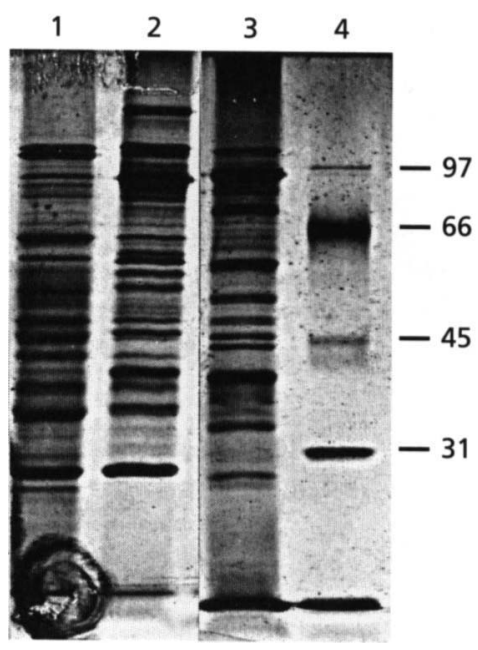

Fig. 1. SDS-PAGE of ammonium-sulphate-precipitated proteins from three different strains of $B$. cereus. Lanes: 1 , strain 123088; 2, strain F837-76; 3, strain 0075-95; 4, low-molecular-mass markers. Positions and molecular masses in $\mathrm{kDa}$ of markers are indicated on the right. 


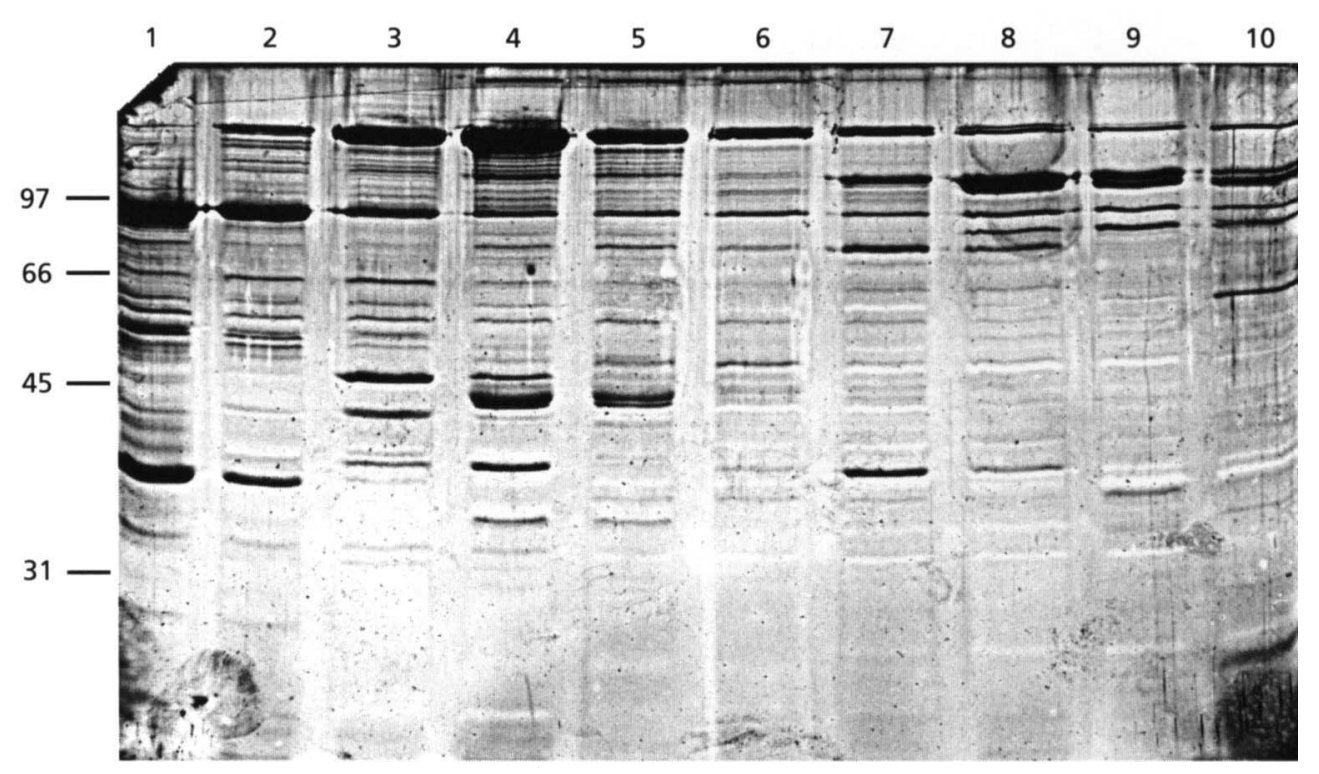

Fig. 2. SDS-PAGE of selected fractions resulting from separation of ammonium-sulphate-precipitated proteins from strain F837-76 by DEAE-Sephacel. Lanes $1-10$ contain fractions 2-11 from the DEAE-Sephacel column, respectively. Positions and molecular masses in $\mathrm{kDa}$ of markers are indicated on the left.

components of $\mathrm{HBL}$ and $\mathrm{NHE}$, and gave results similar to those previously obtained with Whatman DE (Beecher \& Wong, 1994a ; Lund \& Granum, 1996). SDSPAGE of some of the fractions resulting from strain F837-76 is shown in Fig. 2. Fraction 4 was used for further purification for the putative $L_{2}$ protein, seen as a band slightly above $45 \mathrm{kDa}$ in lane 3 . Fractions 5 and 6 were combined for further fractionation of $\mathrm{L}_{1}$ and the $45 \mathrm{kDa}$ protein (putative $45 \mathrm{kDa}$ protein is seen as a doublet just below $\mathrm{L}_{2}$, and above $\mathrm{L}_{1}$ at approximately $37 \mathrm{kDa}$ in lane 4). Fraction 8 was used for purification of the $B$ protein (putative $B$ is seen as a band at approximately $37 \mathrm{kDa}$ in lane 7 ). Fraction 10 was used for purification of the $105 \mathrm{kDa}$ protein (seen as a doublet). The protein of $39 \mathrm{kDa}$ from NHE did not bind to the column at $\mathrm{pH} 6.0$. The elution patterns from the two other strains were similar to that of strain F837-76.

DEAE-Sephacel fractions from the three different strains, corresponding to lane 9 in Fig. 2 were further purified directly on $\mathrm{ReQ}$ at $\mathrm{pH} 7 \cdot 5$. The proteins giving the double band at $105 \mathrm{kDa}$ were eluted between $195 \mathrm{mM}$ and $220 \mathrm{mM} \mathrm{NaCl}$. SDS-PAGE (Fig. 3a, lanes 2-4) revealed that the molecular mass of these proteins from the three strains was nearly identical. The protein in the upper band from strain 0075-95 has previously been referred to as the $105 \mathrm{kDa}$ protein of NHE (Lund \& Granum, 1996). The proteins in the two bands were only partly separated on the ReQ column, and were not separated by chromatography on HA. Tryptic peptides from a fraction enriched for the upper band and a fraction containing mainly the lower band gave nearly identical patterns on SDS-PAGE (not shown). We therefore suggest that the protein in the lower band is a nicked form of the $105 \mathrm{kDa}$ protein.
DEAE-Sephacel fractions from strain F837-76 and strain 1230-88 corresponding to lane 3 in Fig. 2 were further fractionated by HA. Proteins with similar molecular mass to $L_{2}$ (Beecher \& Wong, 1994a) were eluted between $150 \mathrm{mM}$ and $190 \mathrm{mM}$ sodium phosphate. These proteins were finally purified using $\mathrm{ReQ}$ at $\mathrm{pH} 7 \cdot 8$, and were eluted at $90-100 \mathrm{mM} \mathrm{NaCl}$. Purity was evaluated by SDS-PAGE (Fig. 3a, lanes 5 and 6). The identity of $\mathrm{L}_{2}$ from strain $1230-88$ was further established by $\mathrm{N}$-terminal amino acid sequence analysis (Fig. 4). Strain 0075-95 did not express a protein with chromatographic or immunological properties similar to $L_{2}$.

Fractions from DEAE-Sephacel which gave patterns similar to those in lanes 4 and 5 in Fig. 2 were pooled and chromatographed on HA. The putative $45 \mathrm{kDa}$ proteins were eluted at 190-215 mM sodium phosphate. Proteins with the same molecular mass as $\mathrm{L}_{1}$ (Beecher \& Wong, 1994a) from strains F837-76 and $1230-88$ were eluted from $\mathrm{HA}$ at $120-140 \mathrm{mM}$ sodium phosphate.

The $45 \mathrm{kDa}$-like proteins were finally purified by $\mathrm{ReQ}$ at $\mathrm{pH} 7 \cdot 8$, and were eluted at approximately $120 \mathrm{mM}$ (strain 1230), $150 \mathrm{mM}$ (strain 837) and $180 \mathrm{mM} \mathrm{NaCl}$ (strain 0075-95). The purified proteins were analysed by SDS-PAGE (Fig. 3a, lanes 7-10). Strains F837-76 and 0075-95 gave doublet proteins. The doublet proteins from strain 0075-95 were separated from each other when narrow fractions were selected at each purification step (lanes 9 and 10). Digestion of the upper protein with trypsin yielded a fragment with mobility identical to the smaller one (lane 9), indicating a nicked form (not shown). The upper form is identical to the protein previously used in cytotoxicity tests (Lund \& Granum, 1996). The doublet proteins from strain F837-76 are 

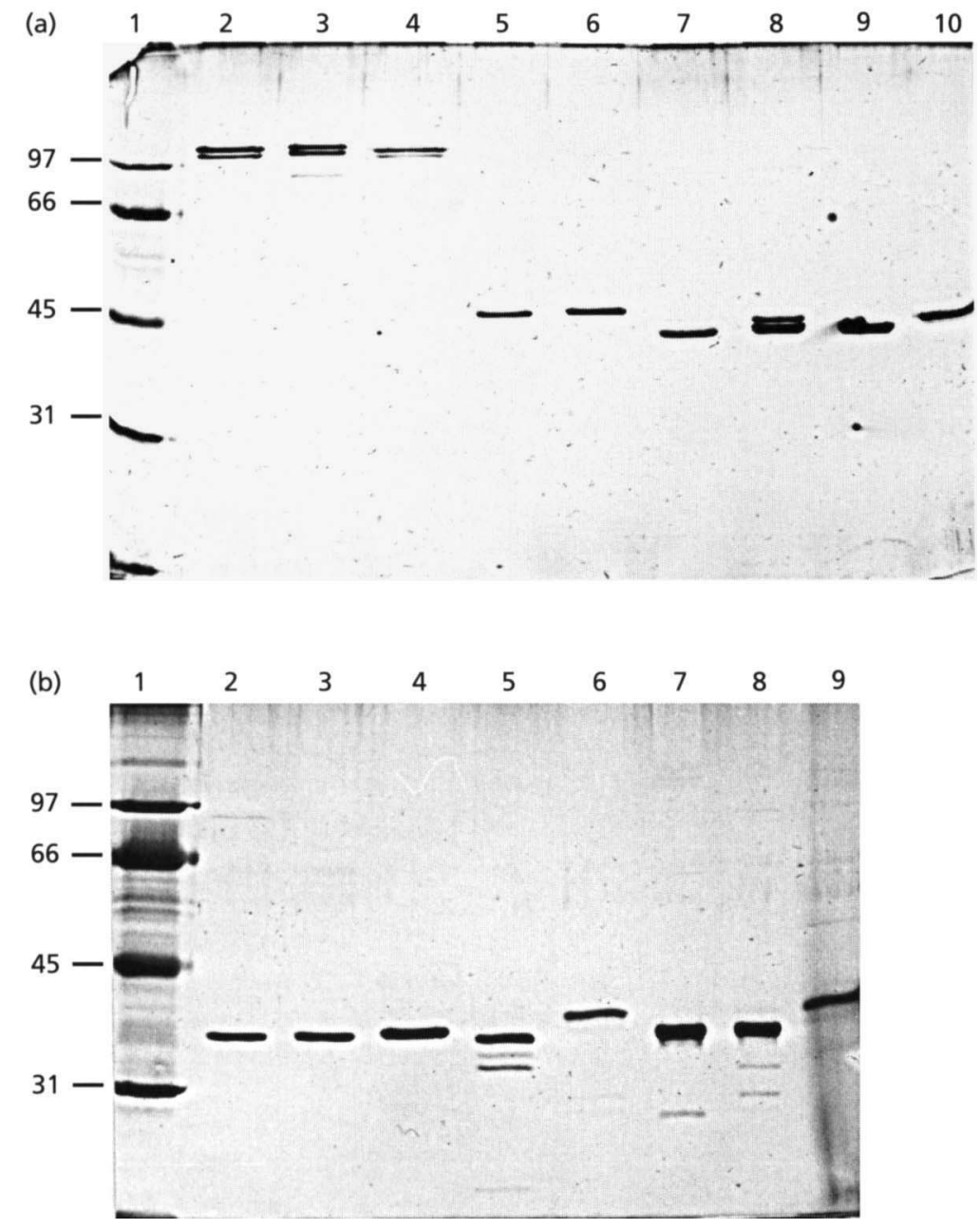

Fig. 3. SDS-PAGE of purified proteins from three different strains of $B$. cereus. (a) Lanes: 1, Low-molecular-mass markers; 2, $105 \mathrm{kDa}$ protein of strain 1230-88; 3 $105 \mathrm{kDa}$ protein of strain F837-76; 4, $105 \mathrm{kDa}$ protein of strain $0075-95 ; 5, L_{2}$ of strain 1230-88; $6, L_{2}$ of strain F837-76; 7 , $45 \mathrm{kDa}$ protein of strain 1230-88; 8, $45 \mathrm{kDa}$ protein of strain F837-76; 9, 10, lower and upper forms, respectively, of $\mathbf{4 5} \mathrm{kDa}$ protein of strain 0075-95. (b) Lanes: 1, Lowmolecular-mass markers; 2, B of strain F837$76 ; 3$, B of strain 1230-88; $4, L_{1}$ of strain F837-76; $5, L_{1}$ of strain 1230-88; $6,39 \mathrm{kDa}$ protein of strain F837-76; $7,39 \mathrm{kDa}$ protein of strain $1230-88 ; 8,39 \mathrm{kDa}$ protein of strain 0075-95 (slightly degraded form); 9, $39 \mathrm{kDa}$ protein of strain 0075-95 (intact form). Positions and molecular masses in $\mathrm{kDa}$ of markers are indicated on the left.
$L_{2}, 1230-88$
$L_{2}, 837-76^{*}$

39 kDa, 837-76

$39 \mathrm{kDa}, 0075-95 \dagger$

Nicked 39 kDa, 0075-95†

$L_{1}, 837-76^{*}$

\section{ETQQEGMDISSS}

ETQQENMDISSS

AESTVKQAPVHVVAKAYNDYE

AESTVKQAPVXAVAKAYNDY

VAKAYNDYEEYSLGPEGLRDAMEXTGSNALVMD

QETTAQEQKVGNYALGPEGLKKALAETGSHILVMD

Fig. 4. Amino acid sequence of the $N$-termini of putative $L_{2}$ from strains $1230-88$ and $F 837-76$, the $39 \mathrm{kDa}$ protein from strains F837-76 and 0075-95 (including a putative nicked form), and $L_{1}$ from strain F837-76. The sequence of $L_{1}$ is aligned to visualize similarity with the nicked $39 \mathrm{kDa}$ protein and the residues in bold indicate identity between them. *, Deduced sequence from Ryan et al. (1997); $\dagger$, from Lund \& Granum (1996); X, uncertain residue.

probably identical to proteins described by Beecher \& Wong (1994b). The N-terminal sequence of the lower form has been shown to be identical to the corresponding part of the $45 \mathrm{kDa}$ protein from strain 0075 95, and according to Beecher \& Wong (1994b) both proteins in the doublet react strongly in the Tecra test.
The $45 \mathrm{kDa}$-like protein from strain 1230-88 (lane 7) was further identified by the immunological Tecra assay. It was detected at $3 \mathrm{ng} \mathrm{ml}^{-1}$, a value corresponding to the those reported previously for the $45 \mathrm{kDa}$ protein from strains F837-76 and 0075-95 (Beecher \& Wong, 1994b; Lund \& Granum, 1996). 
Table 1. Approximate concentrations in ng of components of HBL and NHE necessary for $50 \%$ inhibition of protein synthesis in Vero cells

\begin{tabular}{|lcccccccc|}
\hline Strains & \multicolumn{4}{c}{ NHE } & & \multicolumn{3}{c|}{ HBL } \\
\cline { 2 - 5 } \cline { 6 - 8 } & 39 kDa & $\mathbf{4 5} \mathbf{~ k D a}$ & $\mathbf{1 0 5} \mathbf{~ k D a}$ & & B & $\mathbf{L}_{1}$ & $\mathbf{L}_{2}$ \\
\hline Strain F837-76 & ND & ND & ND & & 30 & 25 & 25 \\
Strain 1230-88 & 30 & 70 & 500 & & 90 & 75 & 70 \\
Strain 0075-95* & 30 & 20 & 20 & & - & - \\
\hline
\end{tabular}

ND, Not determined, but proteins were functional (see text).

- , Not present.

*From Lund \& Granum (1996).

Fractions from HA chromatography containing $\mathrm{L}_{\mathbf{1}}$-like proteins were pooled and applied to $\mathrm{ReQ}$. The $\mathrm{L}_{1}$-like proteins were eluted at approximately $110 \mathrm{mM} \mathrm{NaCl}$ at $\mathrm{pH} 7 \cdot 8$. SDS-PAGE (Fig. 3b, lanes 4 and 5) revealed that the molecular mass of the $\mathrm{L}_{1}$-like protein from strain 1230-88 was close to that of $\mathrm{L}_{1}$ from strain F837-76. Cytotoxicity tests (see below) showed that the $\mathrm{L}_{1}$-like protein from strain $1230-88$ was toxic in combination with $\mathrm{L}_{2}$ and $\mathrm{B}$. This protein is therefore probably a homologue of $L_{1}$ from strain $F 837-76$. No protein with chromatographic properties similar to $\mathrm{L}_{1}$ was detected from strain 0075-95. Proteins from this strain were also used in cytotoxicity tests, together with $B$ and $L_{2}$ from strain F837-76, without cytotoxic effect.

Fractions similar to DEAE-Sephacel fraction 8 (Fig. 2) were used for further purification of B-like proteins by HA. Proteins with molecular mass similar to the B protein were eluted between $180 \mathrm{mM}$ and $210 \mathrm{mM}$ sodium phosphate. These proteins were further purified on $\mathrm{ReQ}$ at $\mathrm{pH} 7.8$ and eluted at $140-160 \mathrm{mM} \mathrm{NaCl}$. SDS-PAGE showed that the B proteins of strains F83776 and 1230-88 were pure and had similar molecular mass (Fig. 3b, lanes 2 and 3). Amino acid sequence analysis of the first $15 \mathrm{~N}$-terminal amino acids of the $\mathrm{B}$ component from strain $1230-88$ were identical to those deduced for the B component from strain F837-76 (Heinrichs et al., 1993). No B-like component was detected from supernatants from strain 0075-95.

The void fraction from chromatography on DEAESephacel was used to purify proteins similar to the $39 \mathrm{kDa}$ protein of strain 0075-95 (Lund \& Granum, 1996). These fractions were applied to a HA column and proteins of approximately $39 \mathrm{kDa}$ were eluted at $105-$ $130 \mathrm{mM}$ sodium phosphate. Chromatography on $\mathrm{ReQ}$ at $\mathrm{pH} \mathrm{8.1} \mathrm{was} \mathrm{the} \mathrm{final} \mathrm{purification} \mathrm{step} \mathrm{(eluted} \mathrm{at}$ $50 \mathrm{mM} \mathrm{NaCl}$ ). The resulting proteins are shown in Fig. $3 \mathrm{~b}$ (lanes 6-9). From strain F837-76 a band appeared (lane 6) that corresponded to the intact $39 \mathrm{kDa}$ protein from strain 0075-95, whilst from strain $1230-88$ a band appeared (lane 7) corresponding to the nicked form of the same protein. The sequence of the first $21 \mathrm{~N}-$ terminal amino acids of the $39 \mathrm{kDa}$ protein from strain F837-76 was determined and compared to the sequence of the $39 \mathrm{kDa}$ protein from strain 0075-95 (Fig. 4). Except for valine substituting for alanine in position 12, the sequence was identical to that of the $39 \mathrm{kDa}$ protein from strain 0075-95.

Toxicity tests on Vero cells showed that $B, L_{2}$ and $L_{1}$ components (in combination) from strains F837-76 and 1230-88 were cytotoxic at low concentrations. Approximately 25-30 ng of each component from strain F837-76 was sufficient for $50 \%$ inhibition of protein synthesis in Vero cells, whilst the corresponding values from strain $1230-88$ were approximately $70-90 \mathrm{ng}$ (Table 1 ). Combinations of two of the components, or single components, were not cytotoxic at comparable concentrations. $\mathrm{L}_{1}$ from strain $1230-88$ used in this test was slightly contaminated with a smaller protein (Fig. 3b, lane 5). This protein was purified, and shown to be non-toxic in combination with $B$ and $L_{2}$.

We have previously shown that NHE isolated from strain $0075-95$ gave $50 \%$ inhibition of protein synthesis in Vero cells using approximately 20-30 ng of each component (Lund \& Granum, 1996). The values for the corresponding proteins from strain $1230-88$ were approximately $30 \mathrm{ng}(39 \mathrm{kDa}$ protein), $70 \mathrm{ng}(45 \mathrm{kDa}$ protein) and $500 \mathrm{ng}$ (105 kDa protein) (Table 1). The $105 \mathrm{kDa}$ protein from strain $1230-88$ was a mixture of the intact protein and the putative degraded form (Fig. $3 a$, lane 2 ). The degraded form bound slightly better than the intact form to ReQ and could therefore be obtained in a nearly pure form. For $48 \%$ inhibition of protein synthesis, $700 \mathrm{ng}$ of the degraded protein was needed, indicating that it contributed less to the cytotoxicity of NHE than the intact protein. In combination with the proteins of $45 \mathrm{kDa}$ and $105 \mathrm{kDa}$ (from strain $1230-88$ ), the $39 \mathrm{kDa}$ protein of strain $0075-95$ could substitute for the $39 \mathrm{kDa}$ protein of strain $1230-88$, further indicating the similarity or identity of these proteins. Different combinations of only two components, in much higher amounts $(2-3 \mu \mathrm{g})$ than used in the experiments above, gave less than $6 \%$ inhibition of protein synthesis in Vero cells.

Cytotoxicity tests with pure proteins of NHE from strain F837-76 in relatively high amounts (194 $\mathrm{ng} 39 \mathrm{kDa}$ protein, $242 \mathrm{ng} 45 \mathrm{kDa}$ protein and $648 \mathrm{ng} 105 \mathrm{kDa}$ 
Table 2. Toxicity to Vero cells caused by addition of the different components of NHE at different times

Vero cells were initially incubated with one of the toxin components for $15 \mathrm{~min}$. Non-bound component was then removed by washing in growth medium and the other two components were added in new medium.

\begin{tabular}{|ccc|}
\hline $\begin{array}{l}\text { Initial protein } \\
\text { component }\end{array}$ & $\begin{array}{c}\text { Additional protein components } \\
\text { added after } 15 \text { min }\end{array}$ & $\begin{array}{c}\text { Inhibition of protein } \\
\text { synthesis (\%) }\end{array}$ \\
\hline $39 \mathrm{kDa}(1 \cdot 5 \mu \mathrm{g})$ & $45 \mathrm{kDa}(200 \mathrm{ng})+105 \mathrm{kDa}(1 \mu \mathrm{g})$ & 6 \\
$45 \mathrm{kDa}(1 \mu \mathrm{g})$ & $39 \mathrm{kDa}(160 \mathrm{ng})+105 \mathrm{kDa}(1 \mu \mathrm{g})$ & 15 \\
$105 \mathrm{kDa}(3 \mu \mathrm{g})$ & $39 \mathrm{kDa}(160 \mathrm{ng})+45 \mathrm{kDa}(200 \mathrm{ng})$ & 92 \\
$105 \mathrm{kDa}(2 \mu \mathrm{g})$ & $39 \mathrm{kDa}(160 \mathrm{ng})+45 \mathrm{kDa}(200 \mathrm{ng})$ & 71 \\
$105 \mathrm{kDa}(1 \mu \mathrm{g})$ & $39 \mathrm{kDa}(160 \mathrm{ng})+45 \mathrm{kDa}(200 \mathrm{ng})$ & 43 \\
\hline
\end{tabular}

protein) gave only $32 \%$ of inhibition of protein synthesis, and no value for $50 \%$ inhibition was estimated. However, the $39 \mathrm{kDa}$ protein $(97 \mathrm{ng})$ and $45 \mathrm{kDa}$ protein $(105 \mathrm{ng})$ from this strain together with the $105 \mathrm{kDa}$ protein $(345 \mathrm{ng}$ ) from strain 0075-95 gave inhibition of $97 \%$. Furthermore, a combination of the $39 \mathrm{kDa}$ protein $(97 \mathrm{ng}$ ) and the $45 \mathrm{kDa}$ protein (105 $\mathrm{ng}$ ) with partly purified $105 \mathrm{kDa}$ component (DEAE-Sephacel fraction 10, Fig. 2) (approximately $400 \mathrm{ng}$ ), all from strain F83776 , resulted in $90 \%$ inhibition. The other proteins of DEAE-Sephacel fraction 10 were tested together with the $39 \mathrm{kDa}$ and $45 \mathrm{kDa}$ proteins and gave no inhibition of protein synthesis.

Cytotoxicity of NHE was also tested with only one of the components added to the Vero cells initially. After $15 \mathrm{~min}$, non-bound component was removed by washing and the other components were added. When the 39, 45 and $105 \mathrm{kDa}$ proteins from strain 1230-88 were tested, a high degree of toxicity was achieved only when the $105 \mathrm{kDa}$ protein was added before washing (Table 2). Combinations of only two components, or the $105 \mathrm{kDa}$ protein alone, at the highest concentrations used, yielded less than $6 \%$ inhibition. The same result was found using components from strain 0075-95.

We also examined if the components of the two enterotoxin complexes could co-operate. In one experiment, using the components from strain 1230-88, B and $\mathrm{L}_{2}$ were added separately and together to the components of NHE in amounts similar to that of the $45 \mathrm{kDa}$ protein (about $100 \mathrm{ng}$ ). When the B component was added the toxicity to Vero cells increased slightly from $52 \%$ to $58 \%$ inhibition. Protein synthesis was inhibited at $66 \%$ with addition of both $B$ and $L_{2}$. When either the $45 \mathrm{kDa}$ or the $105 \mathrm{kDa}$ protein was omitted, the inhibition was reduced to $15 \%$ or less. Co-operation between the components of the two different complexes therefore seems to be limited.

\section{DISCUSSION}

This work has shown that $B$. cereus strains may produce both the HBL and the NHE complexes. The two complexes were cytotoxic at comparable amounts when isolated from the strains from which they were originally characterized (HBL from strain F837-76 and NHE from strain 0075-95). When comparing cytotoxicity based on amounts of protein used it must also be taken into consideration that five of the components have a similar size, whereas the sixth (the $105 \mathrm{kDa}$ protein) has a molecular mass about $2 \cdot 5$-fold higher. Both complexes are probably important $B$. cereus enterotoxins, as judged by analysis of three different strains. For some strains NHE is probably the only functional complex, as in strain 0075-95 where the HBL complex is not present. We have also observed, using Western blots and the same polyclonal antibodies as described by Lund $\&$ Granum (1996), that several strains of $B$. cereus gave bands corresponding to the $39 \mathrm{kDa}, 45 \mathrm{kDa}$ and $105 \mathrm{kDa}$ proteins, whilst a band corresponding to $\mathrm{L}_{2}$ was lacking.

It has been suggested that $\mathrm{L}_{1}$ and the $39 \mathrm{kDa}$ protein could be homologous proteins in the two different strains due to similarities in amino acid sequence and molecular mass (Lund \& Granum, 1996). The gene encoding $L_{1}$ from strain F837-76 has now been cloned and sequenced (Ryan et al., 1997). Comparing this sequence with the amino acid sequence of the $39 \mathrm{kDa}$ protein from strain 0075-95 revealed a stretch of 23 amino acids with $70 \%$ identity (Fig. 4). These two proteins may therefore have similar functions. Strain F837-76, however, expressed another protein, designated the $39 \mathrm{kDa}$, with an N-terminal sequence almost identical to that of the $39 \mathrm{kDa}$ protein of strain $0075-95$ (Fig. 4). The $39 \mathrm{kDa}$ protein of strain F837-76 had toxic properties (was functional together with the other two components of NHE) and chromatographic properties similar to the $39 \mathrm{kDa}$ protein of strain 0075-95, and is therefore probably a true homologue of this protein. We therefore now conclude that the two toxin complexes consist of six different proteins.

The degree of cytotoxicity of the NHE complex appears to vary from strain to strain. This variation is probably first and foremost due to differences in the $105 \mathrm{kDa}$ protein. Indeed, small structural differences between the strains could be detected for this protein. Although the tryptic peptide pattern from the three strains was similar, different peptides could be detected, and long 
SDS-PAGE gels revealed that the mobility of the $105 \mathrm{kDa}$ protein from strain $0075-95$ was slightly faster than the corresponding proteins from the other two strains (not shown). Variation in the toxicity of the $45 \mathrm{kDa}$ protein between strains was also observed.

Nicked forms of different bacterial toxins, produced by bacterial proteases, have been described (Gordon \& Leppla, 1994). The nicking may activate some toxins while others are inactivated. We have detected degraded forms of all the proteins of NHE. The nicked form of the $105 \mathrm{kDa}$ proteins from strain $1230-88$ was less toxic than the intact form. The $105 \mathrm{kDa}$ protein from strain F83776 was probably reduced in activity during the last purification step. Conformational changes due to loss of co-operative components may have caused the inactivation. Taking into consideration the loss of activity of some of the components of NHE during purification, it could be that the intact NHE is much more toxic than the mixture of purified components shows.

In some toxicity tests with NHE, one component was added to the cells at time zero. Unbound protein was washed away before addition of the remaining two components. In these experiments high toxicity was obtained only when the $105 \mathrm{kDa}$ protein was added first, before washing. This protein is therefore most probably the binding protein and the other two components bind to the $105 \mathrm{kDa}$ protein, in a similar manner to the anthrax toxin of Bacillus anthracis (Leppla, 1991). Another possibility is that the two other components bind to structures on the target cells which have to be modified by the binding of the $105 \mathrm{kDa}$ protein. It has previously been suggested that the $B$ protein is the binding component of the HBL complex (Beecher \& Wong, 1994a). The same authors have, however, recently claimed that the interactions between the $\mathrm{HBL}$ components and the target cells are more complicated than first suggested (Beecher \& Wong, 1997).

Polyclonal antibodies raised against partly purified enterotoxin from $B$. cereus have previously been used to identify toxic strains (Beecher et al., 1995; Lund \& Granum, 1996; Thompson et al., 1984). The $105 \mathrm{kDa}$ protein, and probably $\mathrm{L}_{2}$, the $45 \mathrm{kDa}$ protein and the upper form of the $39 \mathrm{kDa}$ protein, may be identified by such antibodies. The mobilities of $\mathrm{B}, \mathrm{L}_{1}$ and the lower form of the $39 \mathrm{kDa}$ protein are, however, too close to allow identification in Western blots with such polyclonal antibodies alone.

The multicomponent diarrhoeal enterotoxin described by Thompson et al. (1984) has previously been compared to HBL and it was claimed from immunological analysis that the two complexes were identical (Beecher et al., 1995). On Western blots (Beecher et al., 1995) it appears, however, that the antiserum developed by Thompson $e t$ al. (1984), in addition to $B, L_{1}$ and $L_{2}$, also recognized proteins corresponding to the $45 \mathrm{kDa}$ and $105 \mathrm{kDa}$ protein of the NHE complex. Thus, it cannot be excluded that the enterotoxin described by Thompson et al. (1984) was a mixture of HBL and NHE.
Neither of the two available commercial immunoassays will completely quantify the toxicity of the enterotoxins from $B$. cereus. The assay measuring $\mathrm{L}_{2}$ (Oxoid) will not detect strains producing only the NHE complex, whilst the other kit, detecting mainly the $45 \mathrm{kDa}$ protein (Tecra), will not detect strains producing only the HBL complex. If one or both of the commercial kits reacts positively with proteins from $B$. cereus supernatants it is likely that the strain is enterotoxin-positive. If the supernatants are also shown to be cytotoxic (on Vero or Caco-2 cells), they can be regarded as enterotoxinpositive. Because variations in cytotoxicity of NHE seem to be mostly due to differences in the $105 \mathrm{kDa}$ component, it is not possible to even estimate activity by using an immunological kit which detects the $45 \mathrm{kDa}$ component. Indeed, we have shown large differences in cytotoxicity between NHE complexes containing the same amount of the $45 \mathrm{kDa}$ protein.

\section{ACKNOWLEDGEMENTS}

This research is supported by grant no. 104984/110 from the Research Council of Norway

\section{REFERENCES}

Beecher, D. J. \& Wong, A. C. L. (1994a). Improved purification and characterization of hemolysin BL, a hemolytic dermonecrotic vascular permeability factor from Bacillus cereus. Infect Immun 62, 980-986.

Beecher, D. J. \& Wong, A. C. L. (1994b). Identification and analysis of the antigens detected by two commercial Bacillus cereus diarrheal enterotoxin immunoassay kits. Appl Environ Microbiol 60, 4614-4616.

Beecher, D. J. \& Wong, A. C. L. (1997). Tripartite hemolysin BL from Bacillus cereus. Hemolytic analysis of component interaction and model for its characteristic paradoxical zone phenomenon. J Biol Chem 272, 233-239.

Beecher, D. J., Schoeni, J. L. \& Wong, A. C. L. (1995). Enterotoxic activity of hemolysin BL from Bacillus cereus. Infect Immun 63, 4423-4428.

Bitsaev, A. R. \& Ezepchuk, Y. V. (1987). The molecular nature of the pathogenic effect induced by B. cereus. Mol Genet Microbiol Virusol 7, 18-23.

Gordon, V. M. \& Leppla, S. H. (1994). Proteolytic activation of bacterial toxins: role of bacterial and host cell proteases. Infect Immun 62, 333-340.

Granum, P. E. (1994). Bacillus cereus and its toxins. J Appl Bacteriol Symp Suppl 76, 61S-66S.

Granum, P. E. (1997). Bacillus cereus. In Fundamentals in Food Microbiology, pp. 327-336. Edited by M. Doyle, L. Beuchat \& T. Montville. Washington, DC: American Society for Microbiology.

Granum, P. E., Brynestad, S. \& Kramer, J. M. (1993). Analysis of enterotoxin production by Bacillus cereus from dairy products, food poisoning incidents and non-gastrointestinal infections. Int $J$ Food Microbiol 17, 269-279.

Heinrichs, J. H., Beecher, D. J., Macmillan, J. M. \& Zilinskas, B. A. (1993). Molecular cloning and characterization of the $b b l A$ gene encoding the B component of hemolysin BL from Bacillus cereus. $J$ Bacteriol 175, 6760-6766.

Kramer, J. M. \& Gilbert, R. J. (1989). Bacillus cereus and other 
Bacillus species. In Foodborne Bacterial Pathogens, pp. 21-70. Edited by M. P. Doyle. New York: Marcel Dekker.

Leppla, S. H. (1991). The anthrax toxin complex. In Sourcebook of Bacterial Protein Toxins, pp. 277-302. Edited by J. E. Alouf \& J. H. Freer. London: Academic Press.

Lund, T. \& Granum, P. E. (1996). Characterization of a nonhaemolytic enterotoxin complex from Bacillus cereus isolated after a foodborne outbreak. FEMS Microbiol Lett 141, 151-156.

Ryan, P. A, Macmillan, J. M. \& Zilinskas, B. A. (1997). Molecular cloning and characterization of the genes encoding the $L_{1}$ and $L_{2}$ components of hemolysin BL from Bacillus cereus. J Bacteriol 179, 2551-2556.
Sandvig, K. \& Olsnes, S. (1982). Entry of the toxic proteins abrin, modeccin, ricin and diphtheria toxin into cells. J Biol Chem 257, 7495-7503.

Thompson, N. E., Ketterhagen, M. J., Bergdoll, M. S. \& Shantz, E. J. (1984). Isolation and some properties of an enterotoxin produced by Bacillus cereus. Infect Immun 43, 1-22.

Turnbull, P. C. B, Kramer, J. M., Jørgensen, K., Gilbert, R. J. \& Melling, J. (1979). Properties and production characteristics of vomiting, diarrheal, and necrotizing toxin of Bacillus cereus. Am J Clin Nutr 32, 219-228.

Received 10 April 1997; revised 2 June 1997; accepted 11 June 1997. 